\title{
Nature of circulating immune complexes in infective endocarditis
}

\author{
JILL BURTON-KEE, P MORGAN-CAPNER,* AND JF MOWBRAY
}

From the *Department of Medical Microbiology, King's College Hospital Medical School, Denmark Hill, London SE5 8RX and the Department of Experimental Pathology, St Mary's Hospital Medical School, London W2 IPG, UK

SUMmaRY Two percent polyethylene glycol (PEG) precipitation was found to be a useful method for detecting circulating immune complexes (CIC) and could be used diagnostically to implicate infective endocarditis. Complexes consisting of at least $\mathrm{Clq}$, IgG, and $\mathrm{IgA}$ were typically detected in sera from patients with infective endocarditis.

Serial studies showed that CIC detection and measurement could be used to monitor clinical progress. Successful clinical improvement was reflected by decreasing CIC levels and the disappearance of rheumatoid factor, and, where increasing amounts of CIC were found, this may indicate situations where treatment was insufficient or inappropriate.

There was specific free antibody demonstrable in the serum of six out of nine patients against their own infecting organisms, but attempts to identify the specificity of the complexed antibody as being directed against these organisms or their extracellular products failed. We could not detect any radioactive precipitin arcs, indicative of the free antibody also being in the complex, between the $F\left(a b^{\prime}\right)_{2}$ preparation from the complex and the electrophoresed bacterial antigens in a radioimmunoelectrophoresis system.

Eleven out of 13 sera that contained $\mathrm{Clq}$, IgG, and $\operatorname{IgA}$ in their complexes also contained rheumatoid factor. Immunisation against the patient's own persisting CIC may explain this phenomenon.

The presence of circulating immune complexes (CIC) is now well documented in infective endocarditis (IE) using a variety of detection methods, ${ }^{1}$ and serial studies have shown that CIC in IE correlate closely with disease activity. ${ }^{2-5}$ We have used $2 \%$ polyethylene glycol (PEG) precipitation before to detect CIC and study their changing levels temporally during plasmaphoresis in patients with immune complex disease $^{6}$ and have now applied this technique to the study of IE before and during antimicrobial therapy.

Bayer $^{2}$ has reported a high incidence of CIC in patients with confirmed IE, and so, in addition to studying a group of 22 cases of proven IE to confirm this, we included 60 cases of 'suspected IE' to see if the presence and composition of any CIC detected could be used diagnostically. As Petersdorf has suggested $^{7}$ that a CIC detection test could be particularly useful in patients who were subsequently diagnosed as having IE, but from whom all blood

Received for publication 2 January 1980 cultures were negative, three were included in this study.

The presence of CIC is thought to result in the glomerular and skin lesions associated with IE. ${ }^{89}$ Various workers have attempted to determine the antigens present in the tissue-deposited complexes in these lesions by a variety of immunofluorescent methods. Burch ${ }^{10}$ demonstrated Coxsackie B4 antigens in the glomerulus and pericardium of a patient with viral pancarditis with renal involvement -at one time thought to have IE-and Shanson ${ }^{11}$ used labelled streptococcal culture medium to stain glomerular sections in cases of IE with renal lesions. Levy and Hong ${ }^{12}$ eluted from glomerular sections antibody that agglutinated culture suspensions of the infecting enterococci; but Boulton-Jones ${ }^{13}$ was unsuccessful in showing specific reactions by an immunofluorescent method (actinobacillus infection) and elution followed by microcomplement fixation (psittacosis infection). Gutman ${ }^{14}$ suggested that the kind of infectious agent involved was not related to 653 
a specific kind of immune-complex mediated damage.

As the antigenic composition of CIC in IE had not previously been demonstrated we attempted to determine whether the immune complex contained antigens from the infecting organisms or antibody specificities for these antigens..$^{15} \mathrm{We}$ initially determined the presence of free antibody in the serum by double diffusion and used $2 \%$ PEG precipitation to isolate the CIC from serum.

\section{Patients and methods}

\section{PATIENTS AND SERA}

Sera from 82 patients, all initially diagnosed as possible cases of IE, were studied from December 1976 to August 1978. Significant bacteria were isolated from blood cultures in 19 of these patients, and, in conjunction with the clinical and investigative findings, a firm diagnosis of IE was made. No significant microorganisms were isolated from three other patients, but their clinical features, and improvement with antimicrobial therapy, were strongly suggestive of IE. These 22 patients are summarised in Table 1. The remaining 60 ('suspected IE') had no significant bacteria grown from blood cultures and were eventually diagnosed as having a variety of other cardiological conditions of a noninfective nature, for example, rheumatic valvular disease.

Control sera for the PEG precipitation test were 97 different samples from healthy laboratory staff with no history of heart disease.
All samples were allowed to clot at room temperature, and the sera were stored at $-70^{\circ} \mathrm{C}$. CIC estimation was usually carried out within two weeks, during which time the sera were not thawed.

\section{DETECTION OF CIC}

$0.5 \mathrm{ml}$ volumes of serum were mixed with $0.1 \mathrm{ml}$ of a $12 \%$ solution of polyethylene glycol (PEG MW 6000 , Hopkin and Williams Limited) containing $60 \mathrm{mM}$ EDTA pH 7.6, in barbitone buffered saline (BBS) and left for 18 hours at $4^{\circ} \mathrm{C}$. The precipitate was washed with a $2 \%$ solution of PEG, containing $10 \mathrm{mM}$ EDTA pH 7.6 in BBS, and then dissolved in $0.5 \mathrm{ml}$ of BBS. The fractions of Clq and IgG that had been PEG precipitated were measured by single radial immunodiffusion (SRID). ${ }^{6} 1617$ SRID was performed using $1 \%$ agarose (Indubiose A37, Microbiolabs Limited) in $40 \mathrm{mM}$ EDTA pH 8.6 and BBS at $37^{\circ} \mathrm{C}$. The total serum Clq and the $\mathrm{Clq}$ remaining in the supernatant after precipitation were also measured. This not only gave an indication of the percent of the total $\mathrm{Clq}$ bound to the CIC but also ensured that all the Clq present in the serum could be measured after PEG treatment by SRID. Table 2 shows that this applies to both normal sera and CIC containing sera. The presence of $\operatorname{IgA}$ in the precipitated complex was detected by double diffusion in agarose, the lower limit of $\operatorname{IgA}$ detection being $11 \mu \mathrm{g} / \mathrm{ml}$. 'Batch control' sera were estimated each time the test was performed, and these results have provided the confidence limits for the test.

CIC were present if the amounts of Clq or IgG in the $2 \%$ PEG precipitate were greater than two

Table 1 Findings in 22 patients studied

\begin{tabular}{|c|c|c|c|c|c|c|c|c|c|c|}
\hline \multirow[t]{2}{*}{ Patient } & \multirow[t]{2}{*}{ Age } & \multirow[t]{2}{*}{$\operatorname{Sex}$} & \multirow[t]{2}{*}{ Blood culture } & \multirow{2}{*}{$\begin{array}{l}\text { Serum antibody } \\
\text { against infecting } \\
\text { organism }\end{array}$} & \multicolumn{2}{|c|}{ Complement $(\%$ normal) } & \multicolumn{3}{|c|}{$C I C$} & \multirow{2}{*}{$\begin{array}{l}\text { Rheumatoid } \\
\text { factor }\end{array}$} \\
\hline & & & & & $\mathrm{CH}_{50}$ & $C 3$ & $\mathrm{Clq}$ & $I g G$ & $\operatorname{IgA}$ & \\
\hline HC & 73 & $\mathbf{F}$ & Strep. faecalis & + & 65 & 94 & & & & + \\
\hline ID & 70 & $\mathbf{M}$ & Sterile & Not done & 110 & 108 & & & & + \\
\hline JS & 46 & $\mathbf{M}$ & Strep. viridans & - & 75 & 96 & & & & + \\
\hline EG & 55 & $\mathbf{F}$ & Staph. epidermidis & Not done & 157 & 110 & & & & - \\
\hline EM & 39 & $\mathbf{F}$ & Strep. viridans & Not done & 130 & 142 & & & & + \\
\hline CJ & 62 & $\mathrm{~F}$ & Strep. mitior & Not done & 74 & 91 & & & & + \\
\hline MC 1 & 30 & $\mathbf{M}$ & Sterile & Not done & 19 & 122 & + & + & + & + \\
\hline MC 2 & 62 & $\mathbf{M}$ & Sterile & Not done & 108 & 97 & & & & - \\
\hline DC & 35 & $\mathbf{M}$ & Staph. epidermidis & Not done & 80 & 102 & & & & + \\
\hline AA & 79 & $\mathbf{M}$ & Strep. viridans & - & 88 & 80 & & & & + \\
\hline IL & 52 & $\mathbf{F}$ & Staph. epidermidis & Not done & 112 & 108 & & & & + \\
\hline JH & 44 & $\mathbf{F}$ & Strep. faecalis & + & 106 & 100 & & & & + \\
\hline LD & 61 & $\mathbf{M}$ & Strep. viridans & Not done & 86 & 69 & & & & + \\
\hline $\mathbf{A F}$ & 60 & $\mathbf{M}$ & Strep. bovis & - & 100 & 101 & & & & + \\
\hline EO & 52 & $\mathbf{M}$ & Staph. epidermidis & Not done & 43 & 128 & + & + & - & - \\
\hline TR & 36 & $\mathbf{M}$ & C. xerosis & + & 98 & 114 & & & & - \\
\hline FW & 69 & $\mathbf{F}$ & Strep. milleri & + & 21 & 112 & + & - & + & + \\
\hline BC & 54 & $\mathbf{M}$ & Staph. epidermidis & + & 108 & 92 & & & & - \\
\hline MG & 25 & $\mathbf{F}$ & Staph. aureus & + & 89 & 100 & & & & Not done \\
\hline $\mathbf{J M}$ & 40 & $\mathbf{M}$ & Strep. faecalis & Not done & 112 & 134 & + & & - & - \\
\hline DL & & $\mathbf{M}$ & Staph. aureus & Not done & 100 & 106 & & & & - \\
\hline BK & 49 & $\mathbf{M}$ & Strep. faecolis & Not done & 120 & 91 & & & & - \\
\hline
\end{tabular}

+ present; - absent. 
Table 2 Recovery of serum Clq after $2 \%$ PEG precipitation

\begin{tabular}{|c|c|c|c|c|c|}
\hline \multirow[t]{3}{*}{ Serum } & \multirow[t]{3}{*}{ No. } & \multicolumn{4}{|c|}{$C l q(\mu g / m l)$} \\
\hline & & \multicolumn{2}{|c|}{ Serum total } & \multicolumn{2}{|c|}{ Rerovery $(P+S)$} \\
\hline & & Mean & $S D$ & Mean & $S D$ \\
\hline \multirow{2}{*}{$\begin{array}{l}\text { Containing CIC } \\
\text { Not containing } \\
\text { CIC }\end{array}$} & 30 & $205 \cdot 2$ & $26 \cdot 3$ & $212 \cdot 7$ & $27 \cdot 6$ \\
\hline & 30 & $198 \cdot 2$ & 17.9 & $211 \cdot 7$ & $28 \cdot 1$ \\
\hline
\end{tabular}

$\mathbf{P}=$ precipitated Clq; $\mathbf{S}=$ supernatant Clq.

All values are calculated using a normal human serum standard of $200 \mu \mathrm{g} \mathrm{Clq} / \mathrm{ml}$ in the SRID plate.

standard deviations above the mean for the "batch control' sera ( 80 estimations) or if IgA was present. These values were $104 \mu \mathrm{g} / \mathrm{ml}$ (mean $44 \mu \mathrm{g}$; SD $30 \mu \mathrm{g}$ ) for Clq and $69 \mu \mathrm{g} / \mathrm{ml}$ (mean $38 \mu \mathrm{g}$; SD $15 \mu \mathrm{g}$ ) for IgG.

\section{RHEUMATOID FACTOR}

The presence of rheumatoid factor was detected by the agglutination of a standard latex globulin reagent by serum (RA-test, Latex-Globulin reagent, Hyland).

\section{COMPLEMENT ESTIMATIONS}

Total serum complement $\left(\mathrm{CH}_{50}\right)$ was measured by a standard functional assay, using the lysis of sensitised sheep red blood cells. Serum C3 was measured by SRID.

\section{SERUM ANTIBODY SPECIFICITY FOR}

BACTERIAL ANTIGENS

$10 \mathrm{ml}$ aliquots of 24-hour nutrient broth cultures were centrifuged at $2000 \mathrm{~g}$ for 20 minutes. The pellets were washed twice with $10 \mathrm{ml}$ of $0.9 \%$ sterile saline and finally re-suspended in $1 \mathrm{ml}$ of $0.9 \%$ sterile saline. These suspensions, and the culture supernatants, were stored at $4^{\circ} \mathrm{C}$ until used.

Serum antibody specificity was shown by double diffusion in $1 \%$ agarose in BBS containing $40 \mathrm{mM}$ EDTA pH 7.6 with $5 \mathrm{~mm}$ diameter wells $5 \mathrm{~mm}$ apart. $40 \mu \mathrm{l}$ of the bacterial pellet or culture supernatant were used against variable amounts of serum from $5 \mu \mathrm{l}$ to $45 \mu \mathrm{l}$. The loaded double diffusion plates were incubated at $37^{\circ} \mathrm{C}$ for a minimum of 48 hours.

\section{PEPSIN DIGESTION AND RADIOACTIVE}

\section{LABELLING OF $\mathrm{F}\left(\mathrm{ab}^{\prime}\right)_{2}$ FROM CIC}

Pepsin digestion of the immune complexes was carried out as previously described.15 $5 \mu$ l of $3 \mathrm{~N}$ acetic acid and $35 \mu l$ of $0.2 \mathrm{~N}$ acetic acid containing $5 \%$ pepsin by weight to give an enzyme/substrate ratio of $1: 50$ were added to the $2 \%$ PEG precipitate.
Digestion at $37^{\circ} \mathrm{C}$ was performed for 6 hours, and the $\mathrm{pH}$ was then raised to 5.0 with $3 \mathrm{~N} \mathrm{NaOH}$ and then to 8.0 with $0.5 \mathrm{M}$ phosphate buffer 8.0.

$10 \mu \mathrm{l}$ of this preparation was iodinated with $\mathrm{Na}^{125 I}$ by Hunter's method. ${ }^{18}$ Labelled protein was separated from the excess iodine by dialysis against saline overnight. The labelled mixture was added to $0.5 \mathrm{ml}$ of the corresponding serum from which it was originally derived to allow precipitation of the $\mathrm{F}\left(\mathrm{ab}^{\prime}\right)_{2}$ with $20 \% \mathrm{Na}_{2} \mathrm{SO}_{4}\left(37^{\circ} \mathrm{C}\right.$ for 30 minutes). The preparation was dialysed overnight against saline and used in the radioimmunoelectrophoresis (RIEP).

\section{RADIOIMMUNOELECTROPHORESIS}

This was carried out using a technique previously described. ${ }^{15}$ Immunoelectrophoresis of the bacterial suspensions and the culture supernatants was performed in a $200 \times 115 \mathrm{~mm}$ plate of $1 \%$ agarose in $50 \mathrm{mM}$ EDTA buffer pH 8.6 for 2 hours at 10 $\mathrm{V} / \mathrm{cm}$. After electrophoresis the troughs were filled with the iodinated $\mathrm{F}\left(\mathrm{ab}^{\prime}\right)_{2}$ of the corresponding CIC contained in the serum from which it was derived.

Plates were left for a minimum of 48 hours in a humid chamber at $37^{\circ} \mathrm{C}$, then washed in saline and stained for protein with Coomassie Blue. A sheet of $x$-ray film was applied to the plate and developed after 10-15 days. Serum antibody was identified from the protein stain by precipitin arcs.

\section{Results}

PRESENCE AND COMPOSITION OF CIC

The presence and composition of CIC in the 22 proven case of IE are shown in Table 1. All of these sera were obtained before antibiotic treatment (except in the case of BK, see serial studies), and all are positive for complement binding complexes shown by the presence of Clq in the PEG precipitate.

Figure 1 shows the presence and absence of CIC in all three groups and the composition of complexes when present. In positive sera the proportions of CIC containing IgA are as follows: proven IE 15/22 $(68 \%)$; suspected IE $19 / 60$ (32\%); controls $6 / 97$ $(6 \%)$. However, there are more CIC containing all three components measured (ie, Clq, IgG, and IgA) in the proven IE group than in the other two groups: proven IE 13/22 (65\%); suspected IE 11/60 (18\%); healthy controls $1 / 97(1 \%)$. The three blood culture negative sera in the proven IE group had complexes containing $\mathrm{Clq}, \mathrm{IgG}$, and $\mathrm{IgA}$.

The amounts of Clq bound to complex in this group compared with the suspected IE group and controls are shown in Figure 2. The amounts of Clq bound to CIC within the groups were as follows: proven IE, mean $180 \pm \mathrm{SD} 56 \mu \mathrm{g} / \mathrm{ml}$; suspected IE, 


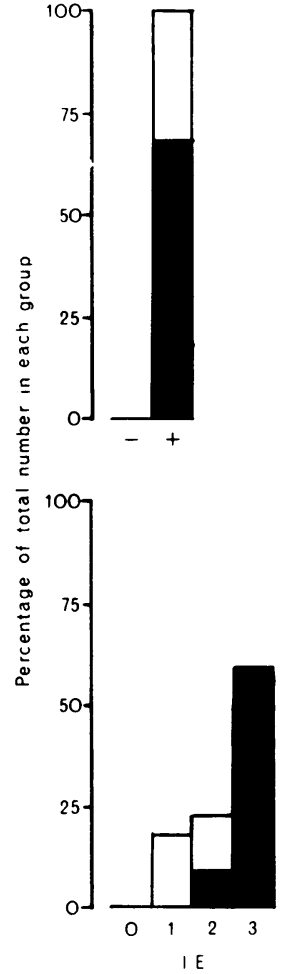

(22)
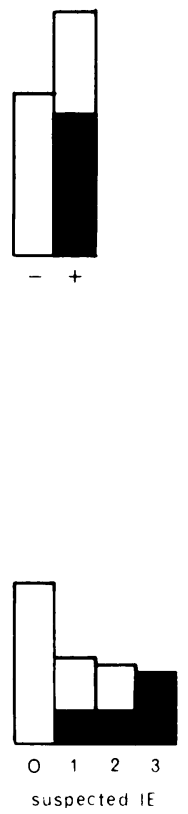

$(60)$

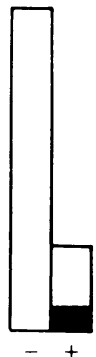

(ii)

(i)

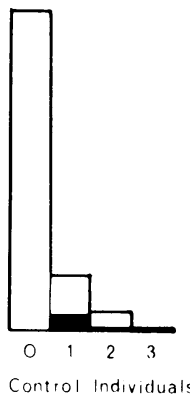

(97)
Fig. 1 (i) Presence (+) and absence (-) of CIC in each group. A positive serum was one that gave a significantly high level of $\mathrm{Clq}, \operatorname{IgG}$, or $\operatorname{Ig} A$ in the $2 \%$ PEG precipitate. (ii) Composition of $\mathrm{CIC}$ in each group: $O=$ absence of $C I C ; 1=$ presence of positive amounts of $C l q, \operatorname{IgG}$, or $\operatorname{Ig} A ; 2=$ presence of positive amounts of $C l q$ and $\operatorname{Ig} G$, or $C l q$ and $\operatorname{Ig} A$, or $\operatorname{IgG}$ and $\operatorname{Ig} A$; $3=$ presence of positive amounts of $C \mathrm{lq}, \operatorname{IgG}$, and $\operatorname{Ig} A$. Ig $A$ present.

mean $119 \pm \mathrm{SD} 67 \mu \mathrm{g} / \mathrm{ml}$; controls, mean $65 \pm \mathrm{SD}$ $38 \mu \mathrm{g} / \mathrm{ml}$. The IE group had significantly more complement binding CIC $(22 / 22,100 \%)$ than the suspected IE group (26/60, $43 \%), \chi^{2} 19.03 \mathrm{P}<0.0005$.

The presence of a positive amount of IgG in the proven IE group compared with the suspected IE group and the healthy controls was 16/22 (73\%), $22 / 60(37 \%)$, and $12 / 97(12 \%)$ respectively. A comparison of the amounts of IgG detected in the $2 \%$ PEG precipitate in the groups is as follows: proven IE, mean $182 \pm \mathrm{SD} 137 \mu \mathrm{g} / \mathrm{ml}$; suspected IE, mean $94 \pm \mathrm{SD} 102 \mu \mathrm{g} / \mathrm{ml}$; healthy controls, mean $53 \pm 35 \mu \mathrm{g} / \mathrm{ml}$.

\section{RHEUMATOID FACTOR}

Table 1 shows the presence of rheumatoid factor within the group. Of those CIC that contain Clq,

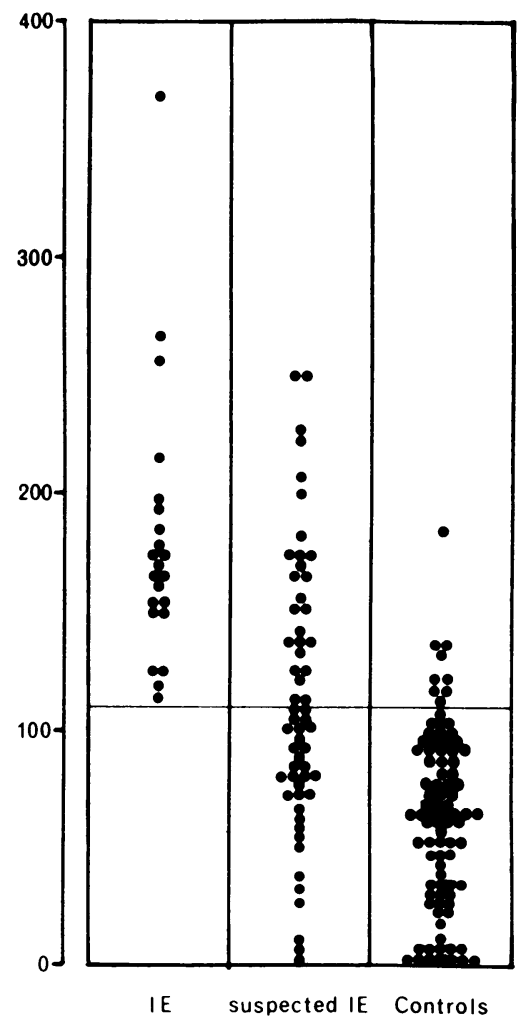

Fig. 2 Amounts of $\mathrm{Clq}(\mu \mathrm{g})$ from $1 \mathrm{ml}$ of serum bound to the CICs isolated from each serum by $2 \%$ PEG precipitation. The horizontal bar represents the upper limit of normal (mean $+2 S D$ ) of the 'batch controls' used (see text).

IgG, and $\operatorname{IgA}, 11 / 13(85 \%)$ were RA latex positive. Where only two or one of these components was positive, $2 / 8(25 \%)$ were RA latex positive. This gives a strong correlation between the presence of CIC detected by this assay and the presence of rheumatoid factor for the proven IE group, $\chi^{2} 5 \cdot 15$, $\mathrm{P}<0.01$. The aetiological organism in each case could not be related to the type of complex detected or to the presence of rheumatoid factor.

COMPLEMENT STUDIES

$\mathrm{CH}_{50}$ and $\mathrm{C} 3$ results are given in Table 1. Although all CIC detected within the group were complement binding, total serum complement was abnormal in only eight samples, six below and two above normal. The range of the levels was $19-157 \%$ normal values. Five out of six sera with low $\mathrm{CH}_{50}$ also contained IgA CIC. Five C3 levels were outside the normal range (80-120\% normal values), one below and four above. 
SERIAL STUDIES

Figures 3 and 4 represent serially studied CIC levels in IE patients. Figure 3 (patient AF) is an example of an uncomplicated recovery with specific antimicrobial chemotherapy. Streptococcus bovis was isolated, and therapy with penicillin was successful in eradicating infection. Figure 4 (patient BK) traces the progress of a patient treated for IE elsewhere where he failed to show clinical improvement. On admission to SMH blood cultures were negative. After changing his antimicrobial therapy the patient quickly recovered clinically.

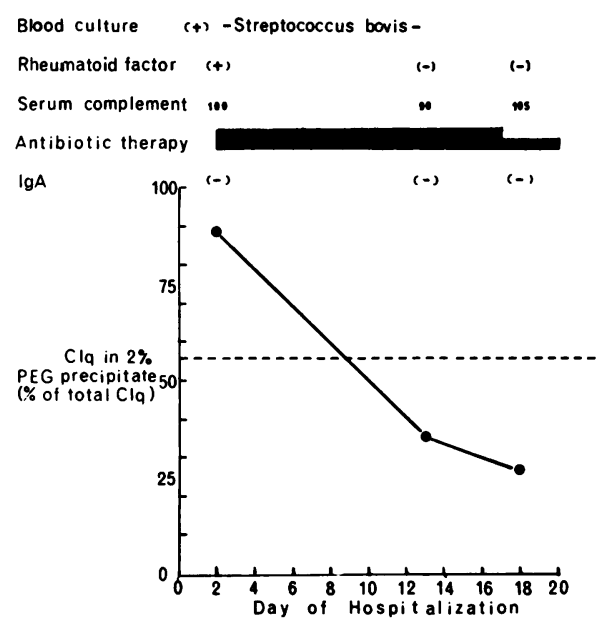

Fig. 3 Patient AF. Antibiotic therapy was penicillin $G$, 2 mega units 6-hourly (intramuscularly), from day 2 to day 17. Then, penicillin $\mathrm{V}, 500 \mathrm{mg}$ qds, from day 18 to day 42. The broken line represents the upper limit of normal for Clq precipitated with $2 \%$ PEG.

$\operatorname{Ig} A=$ presence $(+)$ or absence $(-)$ in the $P E G$ precipitate. Serum complement levels are $\mathrm{CH}_{50}$ units in terms of $\%$ of normal level.

\section{PRESENCE OF SERUM ANTIBODY TO}

\section{AETIOLOGICAL ORGANISM AND RIEP}

Pretreatment sera were used. Bacterial pellet suspensions and bacterial culture supernatants gave identical results. The bacteria from nine patients (Strep. viridans, Strep. faecalis [2 isolates], Strep. bovis, Staphylococcus epidermidis, Staph. aureus [2 isolates], Strep. milleri and Corynebacterium xerosis) were set up in double diffusion against the sera from which they had been isolated and the other eight sera. Six of the nine gave one or more precipitin lines against the sera from which they had been isolated (Table 1). One of these, the Staph. epidermidis culture (patient $\mathrm{BC})$, gave precipitin lines against seven of the other

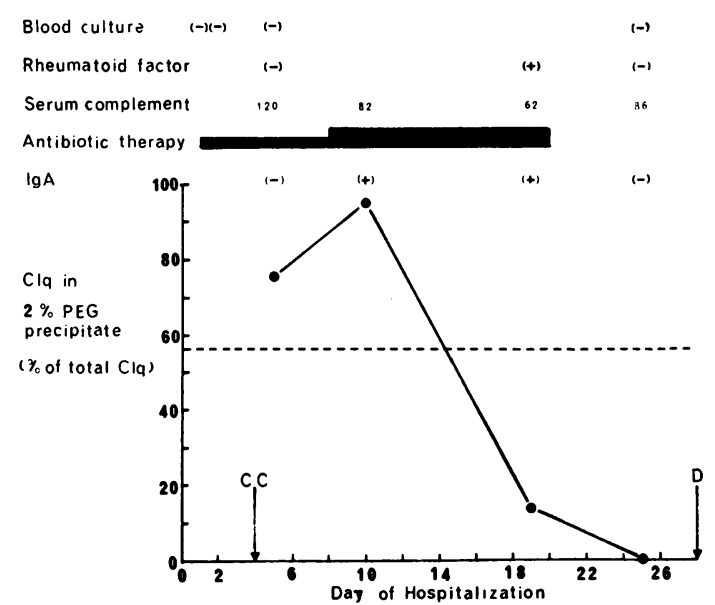

Fig. 4 Patient BK. 14 days and 8 days before admission to SMH Strep. faecalis was isolated from blood cultures, and antibiotic therapy had consisted of $500 \mathrm{mg}$ qds ampicillin, increased to $1000 \mathrm{mg}$ qds after seven days, and amphotericin $B$ four days before admission. At SMH antibiotic therapy was changed to gentamicin and ampicillin. After eight days the dose of gentamicin was doubled as back titration of the patient's serum against the infecting organisms showed inadequate bactericidal activity. IgA refers to $\operatorname{Ig} A$ presence in the $2 \%$ PEG precipitate. The broken line represents the upper limit of normal for Clq precipitated with $2 \%$ $P E G$. Serum complement levels are $\mathrm{CH}_{50}$ units in terms of \% of normal level: $c c$-cardiac catheterisation; $D$-discharge.

sera tested. Two (JH, FW) of these six, which specifically reacted with their 'own' organisms, were used in the RIEP system. In addition, a 'negative' serum not reacting against its own culture in double diffusion (AF) was included to see if the sensitivity of the antibody detection could be improved, using immunoelectrophoresis rather than double diffusion.

When the culture supernatant or the bacterial suspension of bacterial isolate (JH) was electrophoresed, two precipitin arcs could be seen, one in the vicinity of the well and one on the anodic side (a mobility, by comparison with normal human serum (NHS) against anti-NHS included in the run), when the troughs were filled with serum from $\mathrm{JH}$ as a carrier and ${ }^{125} I$-labelled $F\left(a b^{\prime}\right)_{2}$ in the trough. These precipitin arcs were not radioactive.

The RIEP of FW similarly gave some protein arcs in the $a$-region, but none was radioactive.

No precipitin arcs could be seen when the bacterial antigens of AF were electrophoresed and serum of AF was in the trough. The RIEP system did not improve the double diffusion sensitivity in this case. No radioactive lines were seen. 


\section{Discussion}

We have shown by our simple routine method of $2 \%$ PEG precipitation from serum that CIC were present in all the proven cases of IE that we studied, confirming that this test may be a useful diagnostic aid, as suggested by Schur. ${ }^{19}$ Petersdorf ${ }^{7}$ additionally suggested that a CIC detection technique should be particularly useful in cases where IE was implicated but no significant organisms were grown from blood culture. We obtained positive Clq levels in the PEG precipitates from all the sera obtained from patients with a proven diagnosis of IE, before antimicrobial treatment, including those sera from individuals whose blood cultures were sterile. These results are similar to those of Mohammed, ${ }^{1}$ who used three different methods of CIC detection in a small group of sera (7/7 positive) using a radiolabelled Clq binding assay, and of Bayer ${ }^{2}$ using a Raji cell assay (28/29 positive).

We found that a high proportion of $\mathrm{CIC}$ in the proven IE group contained IgA (15/22). The presence of IgA in CIC from IE has not previously been shown. A mixture of Clq, IgG, and IgA was the characteristic composition of CIC in the proven IE group, the presence of this type of complex in the suspected IE and control groups being much less, 19/60 (32\%) and $6 / 97(6 \%)$ respectively. Thus this test can be a useful method to diagnose IE. Lack of Clq in the CIC from a patient's serum would virtually eliminate a diagnosis of IE; and the presence of a Clq, IgG, and IgA type of complex would make IE diagnosis more likely.

Other workers have shown that measurement of the level of CIC may be used to follow an individual's progress during treatment. Raji cell and bovine conglutinin assays have been used in this way by Bayer ${ }^{2}$ and Pussel, ${ }^{5}$ using a radiolabelled Clq binding assay. Our results show that $2 \%$ PEG precipitation may be used in the same way, and although it is less sensitive than the other assays it is consistent enough for serial studies. We have given examples of two situations (Figs 3 and 4) to illustrate the value of a serial study. In Fig. 3, the situation was uncomplicated, and appropriate antimicrobial therapy was followed by clinical improvement, a reduction in the level of CIC, and the disappearance of detectable rheumatoid factor. Figure 4 represents a case where the initial antimicrobial therapy was clearly inappropriate, confirmed by increasing levels of CIC. With effective treatment the CIC levels eventually became normal, reflecting a clinical improvement. The appearance and disappearance of rheumatoid factor during this time is interesting and suggests a possible composition of the CIC. Williams and Kunkel ${ }^{20}$ suggested that rheumatoid factor could be used as a diagnostic aid for IE since their blood culture negative patients showed decreasing titres of rheumatoid factor during clinical improvement, and the patients of Messner et al.,21 who had had a duration of active IE for more than six weeks, had a high proportion of latex positivity, there being $47 \%$ positivity in their whole series. We did not determine rheumatoid factor titres in this study, but examination of Table 1 shows 11 of 13 people with Clq, IgG, and IgA CIC also had rheumatoid factor and $13 / 22(59 \%)$ of the group as a whole. It may be that patients become 'immunised' to their immune complexes when they persist in the serum.

We were interested to determine whether we could detect exogenous antigenic specificity in the antibody from the immune complexes isolated by PEG precipitation. We were unable to do so, even though we had previously determined that there was antibody to soluble exogenous antigen from the bacterial isolate in the pretreatment serum. No study has confirmed the presence of exogenous antigen in the circulating complexes in IE, although Levy and Hong ${ }^{12}$ showed that enterococcal antibody could be eluted from the kidney of a patient with IE, and Shanson and Hince ${ }^{22}$ have demonstrated serum antibody to the infecting organisms in a group of patients with streptococcal IE using an immunofluorescent technique. Our attempts to determine the complexed antigen may have failed because (i) the technique was too insensitive (but we could detect specific serum antibody by double diffusion), or (ii) the antigen in the complex was not protein, therefore not pepsin digestible and so $F\left(a b^{\prime}\right)_{2}$ was not produced, or (iii) the antigens present in the CIC were not exogenous bacterial antigens but host components.

Gutman ${ }^{14}$ suggested that fibrin could be a possible complexed antigen, since it was usually shown to be present in the characteristic focal emboli in the renal lesions of IE. Other attempts to determine endogenous complexed or circulating antigens have been inconclusive. For example, Mohammed ${ }^{1}$ showed that three out of seven IE patients had serum autoantibodies, but all to different cellular components.

In conclusion, the sera of proven cases of IE contain a characteristic type of CIC, consisting of $\mathrm{Clq}, \operatorname{IgG}$, and $\operatorname{IgA}$, and the detection of this type of complex could be performed in many laboratories by our simple routine technique. Serial studies can be of particular value to monitor and improve antimicrobial therapy. An attempt to determine the antibody specificity in the immune complex proved unsuccessful, even when specific free antibody was known to be present in the corresponding serum. The presence of rheumatoid factor was significantly 
correlated with the detection of $\mathrm{CIC}$ containing Clq, IgG, and IgA. Immunisation by persisting CIC of antigens derived from infectious agents and antibody seems the most likely explanation of these observations.

\section{References}

${ }^{1}$ Mohammed I, Ansell BM, Holborow EJ, Bryceson ADM. Circulating immune complexes in subacute infective endocarditis and post-streptococcal glomerulonephritis. J Clin Pathol 1977;30:308-11.

${ }^{2}$ Bayer AS, Theofilopoulos AN, Eisenberg R, Dixon FJ, Guze LB. Circulating immune complexes in infective endocarditis. $N$ Engl J Med 1976;295:1500-5.

${ }^{3}$ Bayer AS, Theofilopoulos AN, Eisenberg R, Friedman SG, Guze LB. Thrombotic thrombocytopenic purpura-like syndrome associated with infective endocarditis. A possible immune complex disorder. JAMA 1977;238: 408-10.

4 Eisenberg RA, Theofilopoulos AN, Dixon FJ. Use of bovine conglutinin for the assay of immune complexes. J Immunol 1977;118:1428-34.

5 Pussell BA, Lockwood CM, Scott DM, Pinching AJ, Peters DK. Value of immune-complex assays in diagnosis and management. Lancet 1978;2:359-64.

- Mowbray JF, Burton EJ. Clinical relevance of the determination of circulating immune complexes. In: Touraine JL et al., eds. Transplantation and Clinical Immunology: Proceedings of the 8th International Course, Lyons, 1976;35-43.

${ }^{7}$ Petersdorf RG. Immune complexes in infective endocarditis. N Engl J Med 1976;295:1534-5.

${ }^{8}$ Keslin MH, Messner RP, Williams RC, Jr. Glomerulonephritis with subacute bacterial endocarditis. Arch Intern Med 1973;132:578-81.

- Davis JA, Weisman MH, Dail DH. Valvular disease in infective endocarditis. Arch Intern Med 1978;138:480-3.

${ }^{10}$ Burch GE, Colcolough HL. Progressive Coxsackie viral pancarditis and nephritis. Ann Intern Med 1969;71: 963-70.

11 Shanson D. Infections of the heart. Medicine (Oxford) 1978; Ser 3, pt. 4:201-6.
${ }^{12}$ Levy RL, Hong $\mathrm{R}$. The immune nature of subacute bacterial endocarditis (SBE) nephritis. Am J Med 1973; 54:645-52.

${ }^{13}$ Boulton-Jones JM, Sissons JGP, Evans DJ, Peters DK. Renal lesions of subacute infective endocarditis. $\mathrm{Br} \mathrm{Med}$ $J$ 1974;2:11-4.

14 Gutman RA, Striker GE, Gilliland BC, Cutler RE. The immune complex glomerulonephritis of bacterial endocarditis. Medicine (Baltimore) 1972;51:1-25.

${ }^{15}$ Dambuyant C, Burton-Kee J, Mowbray JF. The use of the preparation of $F\left(a b^{\prime}\right)_{2}$ antibody from soluble immune complexes, to determine the complexed antigens. $J$ Immunol Methods 1978;24:31-8.

${ }^{16}$ Kazatchkine M, Mowbray JF, Burton EJ, Sultan Y. Circulating immune complexes in haemophilia. Clin Res 1978;26:350A.

${ }^{17}$ Burton-Kee EJ, Lehner T, Mowbray JF. Antigens in circulating immune complexes of Behçet's Syndrome. In: Lehner T, Barnes CG, eds. Proceeding of Multidisciplinary Symposium on Behçets Syndrome. New York and London: Academic Press 1980;44-54.

${ }^{18}$ Hunter WM. Radioimmunoassay. In: Weir DM, ed. Handbook of Experimental Immunology. 2nd ed. Oxford and Edinburgh: Blackwell Scientific Publications, $1973 ; 17.1$.

19 Schur PH. Immune complex assays: the state of the art. $N$ Engl J Med 1978;298:161-2.

${ }^{20}$ Williams RC, Jr, Kunkel HG. Rheumatoid factor complement, and conglutinin aberrations in patients with subacute bacterial endocarditis. J Clin Invest 1962;41: 666-74.

${ }^{21}$ Messner RP, Laxdal T, Quie PG, Williams RC, Jr. Rheumatoid factors in subacute bacterial endocarditisbacterium, duration of disease, or genetic predisposition? Ann Intern Med 1968;68:746-56.

${ }^{22}$ Shanson DC, Hince CJ. An immunofluorescent method of detecting antibodies against viridans streptococci in Streptococcus viridans endocarditis. J Clin Pathol $1978 ; 31: 292-3$.

Requests for reprints to: Mrs J Burton-Kee, Wellcome Laboratories of Experimental Pathology, Variety Club Research Wing, St Mary's Hospital Medical School, London W2 1PG, UK. 